\title{
ENGLISH FOR SPECIFIC PURPOSES VS GENERAL ENGLISH
}

\section{Maria Prokopchuk ${ }^{1}$ \\ Lilia Vinnikova ${ }^{2}$}

DOI: https://doi.org/10.30525/978-9934-26-050-6-51

According to the English for Specific Purposes (ESP) Curriculum the aim of learning is developing not a separate set of language tools but an integrated system of skills in order to be used in situational and professional communication [1, p. 5].

In order to achieve the main aim, an appropriate level of ESP competence is developed, consisting of foreign language knowledge, language, communicative skills as well as general technical skills.

As a result, learning as a model of real communication diminishes the language tool set in order to satisfy the certain students' needs. Authentic teaching materials are also supposed to be used to provide the professionally focused communication under the conditions of intercultural communication [2, p. 7].

Mentioned above language knowledge, skills to use a set of lexical, grammatical tools builds up the premise for further self-work with ESP corresponding to educational challenges and harmonic unity of learning and future professional activities.

Thus commutative situations that are typical for professional domain encourage students to use ESP in class and make the learning process as close as possible to natural professional communication.

Relatively, ESP competence is considered to be a complex personal issue, developed during the language learning and consisting of linguistic,

\footnotetext{
${ }^{1}$ Kyiv Borys Grinchenko University, Ukraine

${ }^{2}$ Kyiv Borys Grinchenko University, Ukraine
} 
communicative, social cultural knowledge, professional skills and certain set of values that based on personal experience and revealed when a learner is ready to perform successfully in the professional arena.

Traditionally ESP academic curriculum is developed for intermediate and advanced levels. Still, the number of ESP learners is increasing drastically these days which can be explained by:

1) a growing ESP interest among learners all over the world;

2) the popularity of English as the main tool of international communication under globalization processes (more and more learners are using English to gain professional knowledge and develop appropriate professional skills);

3) improving the general level of knowing foreign languages and as a result a growing number of younger generations who are eager to learn ESP [3].

On the other hand, specific conditions of professional activities, the system of vocational bonds, technological, social and psychological aspects shpuld be taken into consideration:

1) ESP learning is thought to be a tool to achieve a professional aim that overcomes the border of formal linguistics;

2) previous unsuccessful foreign language learning can have a negative impact on the motivation of ESP learning;

3) ESP can be learnt after working hours or along with professionally focused disciplines that can cause physiological and physical tiredness and make a student be indifferent to the events in the learning theatre;

4) ESP can be learnt on demand of the authorities but not according to the learner's wish;

5) there might be learners of different language levels to study ESP in the same group that make a teacher search for more efficient strategies and use differentiated approach;

6) bosses and coordinates study ESP in one group;

7) different professional field students study ESP in one group;

8) discrepancy in ESP students' levels and the curriculum demands [4, p. 10].

To recapitulate said above, one can arrive at the conclusion that ESP learning should be focused on satisfying the professional students' needs; be organized on the premises of general principals of professional teaching as well as special methodological principals (presupposing content, methods and directions of pedagogical influence on the learner to help the latter achieve the appraise ESP level); take into account technological, social and psychological issuers of ESP learning; use additional motivation tools to diminish the influence of negative previous foreign language experience. 


\section{References:}

1. Bakaieva, H.Ie., Borysenko, A.O., Zuienok, I.I., Ivanishcheva, V.O., Klymenko, L.I. \& Khodtsevab A.O. (2005). Prohrama $\mathrm{z}$ anhliiskoi movy dlia profesiinoho spilkuvannia [English for Specific Purposes (ESP). National Curriculum for Universities]. Kyiv: Lenvit. (in Ukrainian)

2. Zaiarna, I.S. (2019). Metodyka dystantsiinoho navchannia anhliiskoho arhumentatyvnoho pysemnoho movlennia maibutnikh pravoznavtsiv [Methodology for distance teaching English argumentative writing to prospective legal professionals] (Master's thesis), Taras Shevchenko National University of Kyiv, Ministry of Education and Science of Ukraine, Kyiv. (in Ukrainian)

3. Pearson Global Learner Survey (2019). Kontseptualni zasady derzhavnoi polityky shchodo rozvytku anhliiskoi movy u sferi vyshchoi osvity [English Development in Higher Education State Policy Conceptual Framework] Retrieved from https://mon.gov.ua/ua/news/mon-stvorilo-koncepciyu-rozvitku-anglijskoyi-vuniversitetah-u-dodatku-riven-v1-obovyazkova-umova-vstupu-v2-vipuskuvikladannya-profilnih-disciplin-inozemnoyu-ta-movni-skriningi (in Ukrainian)

4. Harding Keith. English for Specific Purposes. Oxford : Oxford University Press, 2007. $170 \mathrm{p}$. 